\title{
The effects of phosphite on strawberry yield and fruit quality
}

\author{
E. Estrada-Ortiz ${ }^{1}$, L. I. Trejo-Téllez ${ }^{1 *}$, F. C. Gómez-Merino², R. Núñez-Escobar ${ }^{1}$ and M. Sandoval-Villa \\ ${ }^{1}$ Colegio de Postgraduados, Campus Montecillo, Carretera México-Texcoco km 36.5. C. P. 56230, Montecillo, Texcoco, Estado \\ de México. ${ }^{2}$ Colegio de Postgraduados, Campus Córdoba, Carretera Córdoba-Veracruz Km 348, C. P. 94946, Amatlán de los \\ Reyes, Veracruz. "Corresponding author: tlibia@colpos.mx
}

\begin{abstract}
Phosphite $\left(\mathrm{H}_{2} \mathrm{PO}_{3}^{-}\right.$; Phi) has been shown to increase fruit quality and activate plant defense mechanisms in plants when provided in a nutrient state with sufficient phosphorous. In this study, five solutions containing different percentages of Phi $(0,20,30,40$ and 50\%) in Steiner's solution were evaluated during the flowering and fructification stages; the Steiner's nutrient solution was kept al 50\% during the flowering stage and at $75 \%$ from the beginning of the fructification stage on. The objective was to determine the effects of phosphite on total P concentration in leaves, yield, $\mathrm{pH}$, electrical conductivity (EC), anthocyanin concentration, and fruit size of strawberries (cv. Festival). The experiments were performed in a tunnel-type greenhouse using drip irrigation and volcanic rock (volcanic gravel) as substrate. In the fruit development phase, the concentration of $\mathrm{P}$ in the leaves was proportional to the level of Phi used. Although no significant differences were observed when compared to the control, the addition of $20 \%$ Phi slightly improved yield and fruit size. The highest $\mathrm{pH}, \mathrm{EC}$ and anthocyanin concentration were identified in the fruit of plants treated with $30 \%$ Phi. Our findings suggest that supplying Phi at $30 \%$ or less in the nutrient solution does not significantly affect yield but does affect fruit quality and activates plant defense mechanisms by producing a higher concentration of anthocyanins.
\end{abstract}

Keywords: Fragaria x ananassa Duch, anthocyanins, electrical conductivity of fruit, $\mathrm{pH}$ of fruit, fruit size

\section{Introduction}

Phosphite $\left(\mathrm{H}_{2} \mathrm{PO}_{3}^{-}\right)$is an isostere of the phosphate anion $\left(\mathrm{H}_{2} \mathrm{PO}_{4}^{-}\right)$in which one of the oxygen atoms bonded to the $\mathrm{P}$ atom is replaced by hydrogen (Ouimette and Coffey, 1990). Due to the structural similarity of these anions and the kinetic properties of plant phosphate transporters, phosphite is transported by high-affinity phosphate transporters (D'arcy-Lameta and Bompeix, 1991). Although phosphite can be transported into the interior of the cell, the ion is not involved in $\mathrm{P}$ metabolism (ATP production, photosynthesis or respiration), and the similarity between phosphate and phosphite seems to be related only to $\mathrm{P}$ assimilation. Phosphite is not converted to phosphate inside the plant and does not participate in any biochemical pathways (Varadarajan et al., 2002), but it does disrupt the phosphorylation of proteins during phosphate deficiency. In Arabidopsis, phosphite suppresses the activity of nucleolytic enzymes, the expression of acid phosphatases, and the genetic carriers of phosphate (Ticconi et al., 2001). Phosphite has also been shown 
to have a fungicidal effect on oomycetes (Orovic et al., 2008), particularly on the genus Phytophthora (Lobato et al., 2008; Rebollar-Alviter et al., 2010).

The reported effects of phosphite on plant growth and yield have been contradictory. In species such as Allium cepa and Brassica nigra, negative effects were reported (Sukarno et al., 1993), but these effects were attenuated by administering phosphate (Varadarajan et al., 2002). However, Moor et al. (2009) found that fertilizing with phosphite did not affect strawberry growth or yield compared with traditional phosphate fertilization, although, it did increase the quality of the fruits by activating the synthesis of ascorbic acid and anthocyanins. On the other hand, Rickard (2000) reported that foliar phosphite increased the yield and quality of several cultivars. Furthermore, applying phosphite as a source of phosphorous had detrimental effects on plants suffering from phosphorous deficiency (Mcdonald et al., 2001; Singh et al., 2003; Lee et al., 2005; Schroetter et al., 2006). On the other hand, applying phosphite to plant roots in the presence of sufficient phosphorous was synergistic, promoted the absorption of phosphorous into tomato plants (Bertsch et al., 2009), and suppressed the negative effects of phosphite (Varadarajan et al., 2002). Thus, the effects of phosphite on plants depend strongly on the phosphorous state of the plant (Thao and Yamakawa, 2009).

Based on previous studies, a nutrient solution containing sufficient phosphorous in the form of phosphate was used for strawberry (cv. Festival). We evaluated the effects of different percentages of phosphite added to the nutrient solution on the concentration of total P in leaves and the activation of the antioxidant system, which determines the concentration of anthocyanins, yield, $\mathrm{pH}$, electrical conductivity (EC), and strawberry fruit size.

\section{Materials and Methods}

\subsection{Experimental conditions}

The study was performed in a tunnel-type greenhouse located at $19^{\circ} 29^{\prime} \mathrm{N}, 98^{\circ} 53^{\prime} \mathrm{W}$, at an altitude of 2,250 m. The diurnal temperature averaged $24{ }^{\circ} \mathrm{C}$, while the nocturnal temperature averaged $11^{\circ} \mathrm{C}$. The luminosity averaged $530 \mathrm{mmol} \mathrm{m}^{-2} \mathrm{~s}^{-1}$.

\subsection{Plant material}

Strawberry plants (Fragaria $x$ ananassa Duch., cv. Festival) were established in red volcanic rock previously sifted to a particle size of 3 to $5 \mathrm{~mm}$ in diameter and placed in $30 \times 30 \mathrm{~cm}$ black polyethylene bags. The distance between the plants was $30 \mathrm{~cm}$ and $1 \mathrm{~m}$ between rows.

\subsection{Treatments and experimental design}

Five nutrient solutions with optimum levels of macroand micronutrients that differed only in the percentage of phosphite $\left(\mathrm{H}_{2} \mathrm{PO}_{3}^{-}\right)$were evaluated. These nutrient solutions were formulated using a modification of the Universal Nutrient Solution of Steiner (1984), where the concentrations for $100 \%$ of $\mathrm{mol}_{\mathrm{c}} \mathrm{m}^{-3}$ are 10.56 $\mathrm{NO}_{3}^{-}, 1.44 \mathrm{NH}_{4}^{+}, 1.0 \mathrm{H}_{2} \mathrm{PO}_{4}^{-} ; 7.0 \mathrm{SO}_{4}^{2-}, 7.0 \mathrm{~K}^{+}, 9.0$ $\mathrm{Ca}_{2}{ }^{+}$, and $4.0 \mathrm{Mg}^{2+}$. The solutions were complemented with a mixture of micronutrients having the following concentrations $\left(\mathrm{mg} \mathrm{L}^{-1}\right)$ : $1.6 \mathrm{Mn}, 0.11 \mathrm{Cu}, 0.865 \mathrm{~B}$, $0.023 \mathrm{Zn}, 0.048 \mathrm{Mo}$, and 5.0 F, where the $\mathrm{Mn}, \mathrm{Cu}$ and $\mathrm{Zn}$ were supplied in the form of sulfates, $\mathrm{B}$ as $\mathrm{H}_{3} \mathrm{BO}_{3}$, Mo as $\mathrm{H}_{2} \mathrm{MoO}_{4}$, and $\mathrm{Fe}$ as Fe-EDTA according to Steiner and van Winden (1970). The concentrations of phosphite evaluated in the nutrient solution were 0,20 , 30,40 and $50 \%$ relative to the total $\mathrm{P}$ in the nutrient solution (phosphate + phosphite). The phosphite was supplied as phosphonic acid $\left(\mathrm{H}_{3} \mathrm{PO}_{3}\right)$, and the $\mathrm{pH}$ was maintained between 5.5 and 5.8 to ensure phosphite availability (Hanrahan et al., 2007). The addition of phosphite was performed during 48 days throughout the flowering phase, using a $50 \%$ Steiner's nutrient solution; and during 135 days in the course of the fruiting phase, using a $75 \%$ solution. A generalized randomized block design (RGB) was used in which each of the five blocks had the treatment applied three times (15 replicates per treatment). The experimental unit was a 30 x $30 \mathrm{~cm}$ black polyethylene bag containing one strawberry plant. 


\subsection{Evaluated variables}

\section{Leaf $P$ concentration}

The plant $\mathrm{P}$ concentration was determined by digesting dry leaf tissue with a mixture of perchloric and nitric acid (Alcántar and Sandoval, 1999). Two sampling dates were carried out: the first one 30 days after treatments, and the second one 131 days after treatments, corresponding to the flowering and fruit development stages, respectively. The extracts were analyzed using inductively coupled plasma atomic emission spectroscopy (ICP-AES) (VARIANTM, Liberty II, Mulgrave, Victoria, Australia).

\section{Yield and fruit size}

Over a four month period (from day 55 through day 183 after Phi treatments application), the total yield was recorded by weighing the fruits from each plant, and individual fruit size was assessed by measuring the fruit length and diameter using Vernier calipers.

\section{Biochemical parameters of fruit quality}

The $\mathrm{pH}$ and $\mathrm{EC}$ were determined from the fruit pulp 122 days after treatments, which was obtained by blending $10 \mathrm{~g}$ of fresh fruit with $50 \mathrm{~mL}$ of distilled water and then inserting a potentiometer (Conductronic, PC18, Puebla, Mexico). The concentration of anthocyanins in the fruit (at day 126 after treatments) was determined using the methods described by Mancinelli et al. (1975), using a 95\% methanol extract and $1.5 \mathrm{~N} \mathrm{HCl}$ in a $85: 15(\mathrm{v} / \mathrm{v})$ proportion and a spectrophotometer (Espectronic 20, Bausch \& Lomb, USA) at $530 \mathrm{~nm}$.

\subsection{Statistical analyses}

First of all, preliminary data analyses were carried out by using the Shapiro-Wilk and Kolmororov-Smirnov tests in order to determine a normal distribution of data; besides, the Levene, O'Brien and Bartlet tests were performed to verify the homogeneity of variance. Subsequently, an analysis of variance (Proc ANOVA) was performed and the means (fixed effects) were compared by a Tukey-test $(\alpha=0.05)$. The analyses were brought about using the Statistical Analysis Systems software, ver. 9.3 (SAS Institute Inc., 2011).

\section{Results and Discussion}

\subsection{Leaf P concentration}

In Figure 1, the total $\mathrm{P}$ concentration in the leaves of plants during flowering and fruit development are shown. Higher concentrations of $\mathrm{P}$ were measured during fruit development, which was independent of the treatment and exhibited a positive correlation with the concentration of phosphite supplied. During the flowering phase, no trend in the total leaf $\mathrm{P}$ concentration was observed that could be attributed to the treatments. Importantly, during the flowering stage, two aspects must be pointed out. Firstly, the interval of $\mathrm{P}$ considered as sufficient for strawberry leaves ranges from 2.5 to $4 \mathrm{~g} \mathrm{~kg}^{-1} \mathrm{DM}$ (Hancock, 1999). Although differences among treatments concerning $\mathrm{P}$ concentrations in leaves during the flowering stage are observed, data obtained in our experiment are considered among those intervals cited above. This indicates that Phi applications did not produce any abnormality in P concentration in leaves (i. e. out of the range described). Accordingly, Ávila et al. (2013) evaluated different dosages of Phi in Phaseolus vulgaris and found that the tissue $\mathrm{P}$ concentration and the total $\mathrm{P}$ accumulation in shoots and roots of $\mathrm{Pi}$ sufficient plants were not significantly affected by Phi treatments applied in nutrient solution. Interestingly, the treatment using the highest level of Phi (50\%) brought about the highest $\mathrm{P}$ concentration in leaves. This response may be attributed to the fact that under this Pi:Phi ratio (50:50) in the nutrient solution, a Pi deficiency may occur, which triggers a higher accumulation of $\mathrm{P}$ in leaves. Similarly, in P. vulgaris Pi-starved plants at the highest Phi level $(512 \mu \mathrm{M}$ Phi) there was a substantial increase in $\mathrm{P}$ concentration, corresponding to 7.2-fold in shoot and 11.7-fold in root (Ávila et al., 2013). 


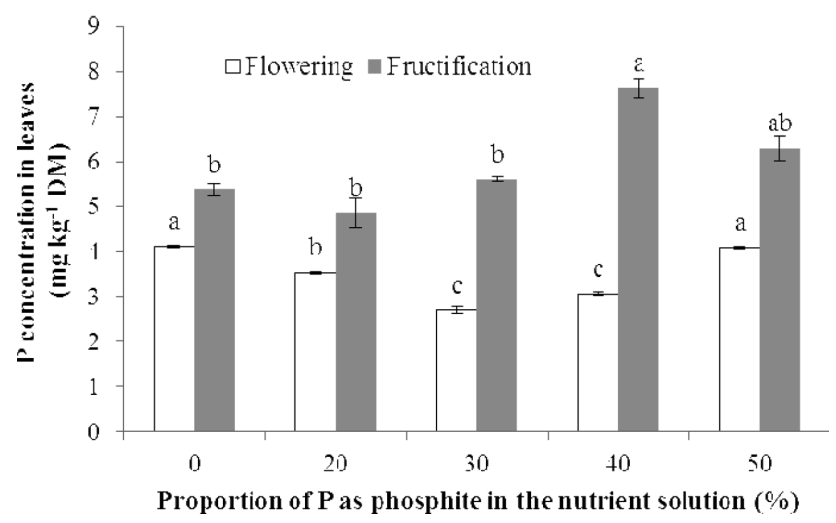

Figure 1. Concentration of $\mathrm{P}$ in strawberry leaves (cv. Festival) treated with five different concentrations of $\mathrm{P}$ as phosphite in the nutrient solution during two phenological phases. Means with different letters are significantly different among treatments. Error bars indicate $\pm \mathrm{SD}$ ( $\mathrm{p}<0.0001$ for $\mathrm{P}$ concentration during the flowering stage; $p=0.0101$ for $\mathrm{P}$ concentration during the fructification stage; $n=5)$.

A)

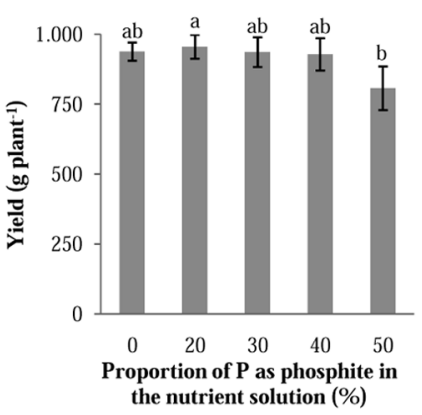

B)

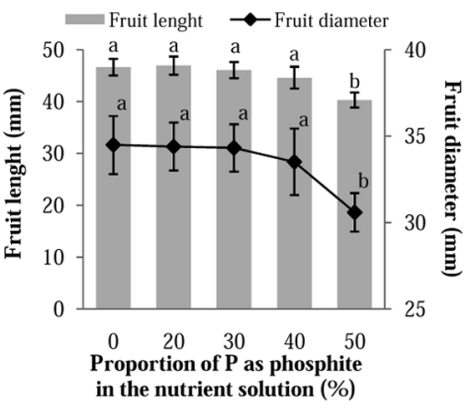

Figure 2. Strawberry (cv. Festival) yield totaled over four months (from 51 to 170 days after treatment) (A) and fruit size (B), during treatment with five different concentrations of phosphorous in the form of phosphite in the nutrient solution. Means with different letters are significantly different among treatments. Error bars indicate \pm SD $[(p=0.0179$ for yield; $\mathrm{n}=10) ;(p<0.0001$ for length and diameter of fruit; $n=32)]$. 
The highest total P content in leaves was observed in plants treated with high concentrations of phosphite (40 and $50 \%$ of the total P) during fruit development (Figure 1). Schink and Friedrich (2000) reported that due to the low redox potential of phosphite oxidation to phosphate, the plants do not utilize phosphite as a source of P. Nevertheless, it has been found that phosphite treatments increase the total $\mathrm{P}$ concentration in lettuce sprouts and roots, and in Japanese spinach (Brassica rapa var. Komatsuna) (Thao and Yamakawa, 2009).

\subsection{Yield and fruit size}

Yield was significantly affected $(p=0.0292)$ by the treatments. The highest yield was obtained by supplying $20 \%$ of the total $\mathrm{P}$ as phosphite $(955.63 \mathrm{~g}$ plant $\left.{ }^{-1}\right)$. However, there were no significant differences between this treatment and the control or with phosphite treatments of $30 \%$ and $40 \%$. Plants treated with $50 \% \mathrm{P}$ as phosphite in the nutrient solution had $15.54 \%$ yield reduction in comparison to those receiving 20\% (Figure $2 \mathrm{~A}$ ).

Watanabe (2005) reported beneficial effects of phosphite on the development of cucumber and the performance of Satsuma oranges. However, Schroetter et al. (2006) ahowed negative effects of foliar phosphite application on performance. Furthermore, these effects were more severe when plants were grown in $\mathrm{P}$ deficient soils. Similarly, Ratjen and Gerendás (2009) found that applying phosphite to soil as a P source for zucchini cultivation caused phytotoxicity, which inhibited the formation of flowers and fruits. In this study, strawberry performance decreased with increasing concentrations of phosphite in the nutrient solution from $30 \% \mathrm{P}$ as $\mathrm{Phi}$ on, though the performance between treatments was not significantly different from the control (Figure 2A). These results are consistent with those reported by Moor et al. (2009), who found that fertilizing strawberry (cv. Polka) with phosphite does not increase yield compared to traditional phosphate fertilization. Moreover, Estrada-Ortiz et al. (2011) reported differential effects of phosphite on strawberry based on the phenological stage and found the fruiting stage to be more sensitive than the flowering stage. The addition of $30 \%$ of the total phosphorus as phosphite stimulated plant metabolism and increased the concentrations of chlorophyll a and $\mathrm{b}$, total amino acids, and proteins in the leaves.

Fruit length was reduced in plants receiving $50 \% \mathrm{P}$ as phosphite in the nutrient solution $(p=0.001)$, and the same trend was observed for fruit diameter (Figure 2B). The remaining phosphite treatments exhibited no significant differences in fruit size compared to the control. A 50:50 ratio of phosphite:phosphate in the nutrient solution significantly reduced the size of the fruit (Figure 2B). Negative effects of Phi increasing levels on plant yield are due to a significant reduction of the availability of $\mathrm{P}$ as phosphate for plants. Although Phi can be uptaken and transported by plants, the ion is not involved in P metabolism and even more, the Phi is not converted into phosphate inside plants (Varadarajan et al., 2002).

\subsection{Biochemical parameters of fruit quality}

Plants treated with the nutrient solution containing $30 \% \mathrm{P}$ as phosphite produced fruit with the highest $\mathrm{pH}(3.41)(p=0.0009)$, which was similar to plants receiving control, $20 \%$ and $40 \%$ phosphite treatments. The treatment with the highest phosphite concentration in the nutrient solution $(50 \%)$ had the most acidic fruits $(\mathrm{pH}=3.30)$ (Figure 3A).

Similarly, the EC also exhibited significant differences among treatments $(p=0.0426)$. The highest $\mathrm{EC}$ value for fruit pulp (1.04 $\left.\mathrm{dS} \mathrm{m}^{-1}\right)$ was obtained using the $30 \%$ phosphite nutrient solution, while the lowest value $\left(0.97 \mathrm{dS} \mathrm{m}^{-1}\right)$ was obtained using the $40 \% \mathrm{P}$ as phosphate solution (Figure $3 \mathrm{~A}$ ). The fruit EC values showed low variation among the treatments, while the $\mathrm{pH}$ of the fruit was highly influenced by the phosphite concentration in the nutrient solution. 
A)

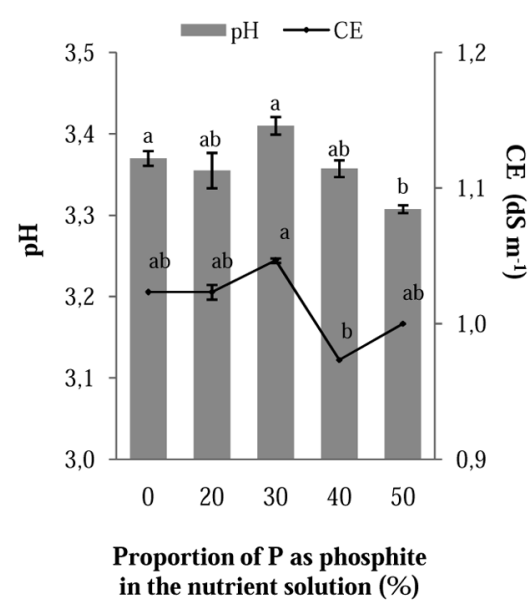

B)

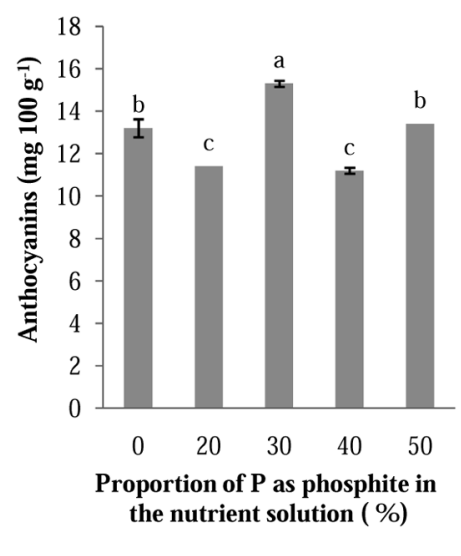

Figure 3. Values of $\mathrm{pH}$ and $\mathrm{EC}(\mathrm{A})$ and anthocyanin concentrations (B) in strawberry (cv. Festival) fruits treated with five different concentrations of $\mathrm{P}$ as phosphite in the nutrient solution. Means with different letters indicate significant differences among treatments. Error bars indicate $\pm \mathrm{SD}[(p=0.0009$ for $\mathrm{pH} ; p=0.0426$ for $\mathrm{EC} ; n=4)$; ( $p=0.0009$ for anthocyanin, $n=5)]$.

The salt concentration in the fruit was little affected by the addition of phosphite, except in plants treated with $40 \%$ phosphite, which had the lowest EC value. On the other hand, fruit $\mathrm{pH}$ was affected more by the treatments (Figure 3A). Pérez de Camacaro et al. (2005) found that fruits with a more acidic $\mathrm{pH}$ had lower quality and were less attractive for fresh consumption. These results support those of Roudeillac and Trajkovski (2004), who showed that the $\mathrm{pH}$ of strawberry fruit should be a minimum of 3.7 , regardless of the cultivar, although no specific information is available for the cv. Festival. The anthocyanin concentrations in the fruit were significantly different among treatments ( $p=0.0009$ ). The treatment with $30 \%$ phosphite nutrient solution had the highest concentration of anthocyanins $\left(15.3 \mathrm{mg} 100 \mathrm{~g} \mathrm{~g}^{-1}\right)$, indicating that this concentration of phosphite had the greatest influence on the plant immune responses (Figure 3B). Likewise, EstradaOrtiz et al. (2012) report that the addition of $20 \% \mathrm{P}$ as phosphite improved some features associated with strawberry fruit quality, including total soluble sugars, Brix, and fruit firmness.

The anthocyanin values obtained from the strawberries (cv. Festival) oscillated between 11.2 and $15.3 \mathrm{mg} 100$ $\mathrm{g} \mathrm{FW}^{-1}$, which is near the lower limit of the interval reported by Da Silva Pinto et al. (2008) for seven different cultivars of strawberry (12.4 to $44.2 \mathrm{mg} 100$ $\mathrm{g} \mathrm{FW}^{-1}$ ). The highest concentration of anthocyanins in fruit was found for the $30 \%$ phosphite treatment, which indicates that this concentration of phosphite in the nutrient solution promoted the production 
of anthocyanins (Figure 3B). Moor et al. (2009) also suggested that adding phosphite increases the concentration of anthocyanins in fruit. In Arabidopsis, anthocyanins accumulation was recorded during $\mathrm{P}$ deficiency and in the presence of phosphite (Ticconi et al., 2001). The importance of anthocyanins, besides functioning as an antioxidant, is directly related to the color of the strawberry fruit (Yoshida et al., 2002). As the concentration of anthocyanins in strawberry fruit increase, the hue angle and luminosity decrease.

\section{Conclusions}

During the fruit development phase, when using a Phi concentration from 20 to $40 \%$ in the nutrient solution, the concentration of $\mathrm{P}$ in the leaves was proportional to the level of phosphite applied. When applying $\mathrm{P}$ as Phi at concentrations up to $40 \%$ in the nutrient solution, no significant effects are observed in comparison to control plants. The $\mathrm{pH}, \mathrm{EC}$ and anthocyanin concentration in the fruit benefited by supplying $30 \%$ phosphite. However, phosphite concentrations equal to or higher than $30 \%$ in the nutrient solution negatively affected fruit performance and quality, indicating that the supply of $\mathrm{P}$ as phosphite was sufficient. Our findings suggest that supplying $20 \%$ phosphite in the nutrient solution improved strawberry (cv. Festival) fruit performance and that supplying $30 \%$ phosphite activated defense mechanisms in the plants, which increased the concentration of anthocyanins and improved fruit quality.

\section{Acknowledgements}

We thank the National Council of Science and Technology (CONACYT) from Mexico for awarding EEO a Master of Science fellowship and to the Priority Research Line 5 (LPI5) from Colegio de Postgraduados for research facilities and support.

\section{References}

Alcántar, G.G., Sandoval, V.M. 1999. Manual de análisis químico de tejido vegetal. Guía de muestreo, preparación, análisis e interpretación. Publicación Especial No. 10 de la Sociedad Mexicana de la Ciencia del Suelo A. C., Chapingo, México.

Ávila, F.W., Faquin, V., da Silva L.A.K., Ávila, P.A., Marques, D.J., Guedes, E.M.S., Tan, Y.D.K. 2013. Effect of phosphite supply in nutrient solution on yield, phosphorus nutrition and enzymatic behavior in common bean (Phaseolus vulgaris L.) plants. Aust. J. Crop Sci. 7, 713-722.

Bertsch, F., Ramírez, F., Henríquez, C. 2009. Evaluación del fosfito como fuente fertilizante de fósforo vía radical y foliar. Agron. Costar. 33, 249265.

D'arcy-Lameta, A., Bompeix, G. 1991. Systemic transport of tritiated phosphonate in tomato plantlets (Lycopersicon esculentum Mill). Pestic. Sci. 32, 7-14.

Da Silva Pinto, M., Lajolo, F.M., Genovese, M.I., 2008. Bioactive compounds and quantification of total ellagic acid in strawberries (Fragaria $x$ ananassa Duch.). Food Chem. 107, 1629-1635.

Estrada-Ortiz, E, Trejo-Téllez, L.I., Gómez-Merino, F.C., Nuñez-Escobar, R., Sandoval-Villa, M., 2011. Biochemical responses in strawberry plants supplying phosphorus in the form of phosphite. Rev. Chapingo Ser. Hortic. 17, 129-138.

Estrada-Ortiz, E., Trejo-Téllez, L.I., Gómez-Merino, F. C., Nuñez-Escobar, R., Sandoval-Villa, M. 2012. Phosphite on growth and fruit quality in strawberry. Acta Hortic. 947, 277-282.

Hancock, J.F. 1999. Strawberries. CABI Publishing. Cambridge, UK. 
Hanrahan, G., Salmassi, T.M., Khachikian, C.S., Foster, K.L. 2005. Reduced inorganic phosphorus in the natural environment: Significance, speciation and determination. Talanta. 66, 435-444.

Lee, T.M., Tsai, P.F., Shyu, Y.T., Sheu, F. 2005. The effects of phosphite on phosphate starvation response of Ulva lactuca (Ulvales, Chlorophyta). J. Phycol. 4, 975-982.

Lobato, M.C., Olivieri, F.P., González, E.A., Wolski, E.A., Daleo, G.R., Caldiz, D.O., Andreu, A. B. 2008. Phosphite compounds reduce disease severity in potato seed tubers and foliage. Eur. J. Plant Pathol. 122, 349-358.

Mancinelli, A., Yang, C., Lindquisr, P., Anderson, O., Rabino, I. 1975. Photocontrol of anthocyanin synthesis III. The action of streptomycin. Plant Physiol. 55, 251-257.

McDonald, A.E., Grant, B.R., Plaxton, W.C. 2001. Phosphite (phosphorous acid): Its relevance in the environment and agriculture and influence on plant phosphate starvation response. J. Plant Nutr. 24, 1505-1519.

Moor, U., Põldma, P., Tõnutare, T., Karp, K., Starast, M., Vool, E. 2009. Effect of phosphite fertilization on growth, yield and fruit composition of strawberries. Sci. Hortic. 119, 264-269.

Orovic, V., Syvertsen, J.P., Bright, D., Van Clief, D.L., Graham, H.J. 2008. Citrus seedling growth and susceptibility to root rot as affected by phosphate and phosphite. J. Plant Nutr. 31, 774-787.

Ouimette, D.G., Coffey, M.D. 1990. Symplastic entry and problem translocation of phosphonate. Pestic. Biochem. Physiol. 38, 18-25.

Pérez de Camacaro, M., Jiménez, A., Terán, Y., Calderón, L. 2005. Physical and chemical quality of strawberry fruits from three years old cultivation at high altitude. Acta Hort. 682, 763-766.
Ratjen, A. M., Gerendás, J. 2009. A critical assessment of the suitability of phosphite as a source of phosphorus. J. Plant Nutr. Soil Sci. 172, 821-828.

Rebollar-Alviter, A., Willson, L.L., Madden, L.V., Ellis, M.A. 2010. A comparative evaluation of postinfection efficacy of mefenoxam and potassium phosphite with protectant efficacy of azoxystrobin and potassium phosphite for controlling leather rot of strawberry caused by Phytophthora cactorum. Crop Prot. 4, 349-353.

Rickard, D.A. 2000. Review of phosphorus acid and its salts as fertilizer materials. J. Plant Nutr. 23, 161-180.

Roudeillac, P., Trajkovski, K. 2004. Breeding for fruit quality and nutrition in strawberries. Acta Hort. $649,55-60$

SAS Institute Inc. 2011. SAS/STAT Users Guide. Version 9.3. SAS Institute Inc., Cary, N. C., USA.

Schink B., Friedrich M. 2000. Bacterial metabolism: Phosphate oxidation by sulphate reduction. Nature. 406, 37-37.

Schroetter, S., Angeles-Wedler, D., Kreuzig, R., Schnug, E. 2006. Effects of phosphite on phosphorus supply and growth of corn (Zea mays). Landbauforsch. Völk. 56, 87-99.

Singh, V. K., Wood, S. M., Knowles, V. L., Plaxton, W. C. 2003. Phosphite accelerates programmed cell death in phosphate-starved oilseed rape (Brassica napus) suspension cell cultures. Planta. 218, 233-239.

Steiner, A. 1984. The Universal Nutrient Solution. In: Proceedings 6th International Congress on Soilless Culture. ISOSC, Wageningen, The Netherlands, pp: 633-649.

Steiner, A., Van Winden, H., 1970. Recipe for ferric salts of ethylenediaminetetraacetic acid. Plant Physiol. 46, 862-863. 
Sukarno, N., Smith, S.E., Scott, E.S. 1993. The effect of fungicides on vesicular-arbuscular mycorrhizal symbiosis: I. The effects on vesicular-arbuscular mycorrhizal fungi and plant growth. New Phytol. $25,139-147$.

Thao, H.T.B., Yamakawa, T. 2009. Phosphite (phosphorous acid): Fungicide, fertilizer or biostimulator?. Soil Sci. Plant Nutr. 55, 228-234.

Ticconi, C.A., Delatorre, C.A., Abel, S. 2001. Attenuation of phosphate starvation responses by phosphite in Arabidopsis. Plant Physiol. 127, 963-972.
Varadarajan, D.K., Karthikeyan, A.S., Matilda, P.D., Raghothama, K.G. 2002. Phosphite, an analog of phosphate, suppresses the coordinated expression of genes under phosphate starvation. Plant Physiol. $129,1232-1240$.

Watanabe, K. 2005. A new fertilizer for foliar application, phosphite fertilizer. Fertilizer. 101, 91-96.

Yoshida, Y., Koyama, N., Tamura, H. 2002. Color and anthocyanin composition of strawberry fruit: Changes during fruit development and differences among cultivars, with special reference to the occurrence of pelargonidin 3-malonyglycoside. J. Jpn. Soc. Hortic. Sci. 71, 355-361. 